\title{
Figures, Illustrations, and Map
}

\section{FIGURES}

Select genealogy of Deobandi scholars from the eighteenth century to the present, 70

Key scholars in the Farangi Mahall school, 80

Scholarly genealogy of the Khairabadi school, 99

Genealogy of the Barelvi school, 101

Periodization of education in India over time, 128

Significant Persian influence impacting the Nizami curriculum, 131

A visual schematization of Islamic moral values, 159

\section{ILLUSTRATIONS}

Faculty and students interacting at Jamica Naeemia, Lahore, Pakistan, 4

Young male students memorizing the Qur'an at a mosque in Srirangapatna, in Karnataka State in India, 18

Author making ablutions (wudu) prior to ritual prayers at one of the mosques of Darul Uloom Deoband in India, 36

Students working on computers at Darul Uloom Deoband, India, 50

Shah Waliyullah's grave in Delhi, India, 95

Statue of Tamerlane outside Ak-Saray Palace in Shakhrisabz, Uzbekistan, 115

Remnants of a historic madrasa built by Mahmud Gawan in Karnataka State in India today, 116

Students interacting with faculty at Jami`a Naeemia, Lahore, Pakistan, 154

Mawlana Anzar Shah Kashmiri, 165

Entrance to the Jami`a Naeemia madrasa in Lahore with antiterrorism security precautions, 167 
Tomb inside the madrasa of Jami'a Naeemia, 168

Children in the town of Deoband in India going to elementary school in traditional clothing, 186

Students in class at Jami'a Naeemia, Lahore, Pakistan, 189

New York Times magazine story giving the impression that all madrasas are run by the Taliban and are linked to terrorism, 208 New marble mosque on Darul Uloom Deoband campus, 243

Doors to mosque of Jamica Naeemia, Lahore, Pakistan, 248

\section{MAP}

Geographical distribution of the main centers of traditional learning in South Asia, 169 